\title{
O propósito das parábolas de Jesus: um estudo exegético de Mc 4,10-12
}

\author{
Orientador: José Otacio Oliveira Guedes \\ Mestrando: Dinis Manuel Nhanga Mona \\ Área de Concentração: Teologia Bíblica
}

Linha de Pesquisa: Análise e Interpretação de Textos do Antigo e Novo Testamento

O propósito das parábolas de Jesus, um estudo exegético de Mc 4, 10-12. Esta pesquisa abordou o propósito do uso de parábolas nos ensinamentos de Jesus, isto é, qual ou quais os motivos que levaram Jesus a usar parábolas em seus ensinamentos. Para alcançar os objetivos traçados, esta pesquisa combinou a metodologia da análise narrativa, algumas vezes da análise retórica, com uma análise dos elementos históricos do texto. Com isto a exegese chegou a um resultado, apresentando outra possibilidade de interpretação da teoria sobre o ensino por parábolas expressa em Mc 4, 10-12. A pesquisa concluiu que na atual configuração há possibilidades de admitir que a perícope referida não afirma que Jesus ensinou por meio de parábolas para endurecer o coração de Seus ouvintes, e dificultar-lhes o acesso as coisas do Reino de Deus. Ao contrário disto a exegese concluiu que Jesus usou parábolas em Seus ensinamentos com o propósito de facilitar o processo de entendimento de todos que $\mathrm{O}$ ouviam, trazendo à compreensão as coisas do Reino de Deus através de uma linguagem que era familiar e natural aos Seus ouvintes.

Palavras-chave: Parábolas. Ensinos de Jesus. Propósito das parábolas. 